\title{
An Evaluation of the Quality of Life in Patients with Knee Osteoarthritis: Adhunik Sadar Hospital, Chapinawabgonj, Bangladesh
} Dr. Md. Abdus Sobhan ${ }^{1 *}$, Dr. Mohammad Mostafizur Rahman ${ }^{2}$

${ }^{1}$ Senior Consultant, Ortho Surgery (Regular), Adhunik Sadar Hoapital, Chapinawabgonj, Bangladesh

${ }^{2}$ Assistant Professor \& Head, Dept. of Anesthesiology \& ICU, Ashiyan Medical College Hospital, Barua Khilkhet, Dhaka, Bangladesh

DOI: $10.36347 /$ sjams.2020.v08i07.022

| Received: 19.06.2020 | Accepted: 27.06.2020 | Published: 21.07.2020

*Corresponding author: Dr. Md. Abdus Sobhan

\section{Abstract}

Original Research Article

Osteoarthritis (OA) is the most common form of arthritis. Osteoarthritis is the most common form of arthritis, affecting millions of people worldwide. It occurs when the protective cartilage that cushions the ends of your bones wears down over time. Although osteoarthritis can damage any joint, the disorder most commonly affects joints in your hands, knees, hips and spine. A cross-sectional descriptive study was conducted to evaluate quality of life in knee OA patients who came to treat in the dept of orthopaedics, Adhunik Sadar hospital, Chapainawabganj, Bangladesh during the period from January 2018 to December 2018. All the data were obtained from direct interview to the patients after getting informed written consent from them. A total of 51 patients were included. The majority of knee OA patients was women $(64.7 \%$ ), age more than 60 years $(41.2 \%)$, and body mass index $(\mathrm{BMI}) 18.5-23.5 \mathrm{~kg} / \mathrm{m} 2$, grade 2 of Kellgren-Lawrence grading system of knee OA (54.9\%), and had no history of knee trauma (92.2\%). Majority of patients did not experience any problem in 5 dimensions of EQ-5D-3L including mobility, self-care, usual activity, pain/discomfort, and anxiety/depression. Some problems mostly appeared in pain/discomfort (76.5\%) and mobility $(31.4 \%)$ dimensions. In this study most of patients did not experience problems in all dimensions. Hence, it showed a good Quality of life in knee OA patients. More attention, proper management, and modification of modifiable risk factors can give positive impact on knee OA patients.

Keywords: Quality of life, Knee osteoarthritis, Pain.

Copyright @ 2020: This is an open-access article distributed under the terms of the Creative Commons Attribution license which permits unrestricted use, distribution, and reproduction in any medium for non-commercial use (NonCommercial, or CC-BY-NC) provided the original author and source are credited.

\section{INTRODUCTION}

Osteoarthritis (OA) is the most common form of arthritis. Osteoarthritis is the most common form of arthritis, affecting millions of people worldwide. It occurs when the protective cartilage that cushions the ends of your bones wears down over time. Although osteoarthritis can damage any joint, the disorder most commonly affects joints in your hands, knees, hips and spine. It is estimated that $10-15 \%$ of adults over the age of 60 experience OA worldwide, whereas the joints most commonly affected are the knee and pelvic joints [1]. OA has multifactorial risk factors, including excess BMI or obesity, older age, trauma to the joints, and excess pressure on the joints caused by exercise or heavy work [1]. Generally, there are two types of OA including primary OA and secondary OA. Primary OA is a chronic degenerative disease associated with the aging process. As a person aged, the water content in the cartilage decreased and makes it more vulnerable to degraded. Secondary OA is caused by specific causes such as injury, work that requires kneeling or squatting for a long time, diabetes, or obesity [2]. The symptoms of OA are often exacerbated by activity and improved with rest. These symptoms also potentially interfere the productivity of patients which can lead to decrease the quality of life $[1,2]$. The diagnosis of OA can be made clinically and radiographically. Diagnosis based on radiography is often used as a standard to determine its presence and the level the severity of OA using the Kellgren and Lawrence grading system (KL) [3]. This study aimed to evaluate the Quality of life of knee OA patients who came into the Orthopedic Clinic at Mangusada Regional General Hospital, Badung, Bali, Indonesia.

\section{Materials ANd Methods}

This research was a cross-sectional descriptive study. The study was conducted at the dept of orthopaedics, Adhunik Sadar hospital, Chapainawabganj, Bangladesh during the period from January 2018 to December 2018. This study using consecutive sampling techniques and a total of 51 patients were included. The inclusion criteria were all of knee OA patients who brought the knee $\mathrm{x}$-ray to the 
Orthopedic Clinic. The exclusion criteria were OA patients other than knee $\mathrm{OA}$ and not willing to be interviewed. Data was collected using the EQ-5D-3L questionnaire [4] and direct interviews with patients. Sources of data regarding the degree of knee OA are taken based on the results of knee $\mathrm{x}$ - ray examination carried by the patient. Degree of knee OA was classified according to the KL [3]. Demographic data, clinical characteristics and quality of life of patients taken include: sex, age, BMI, history of knee trauma, degree of OA, and mobility, self-care, usual activity, and pain/discomfort and anxiety domains. All of the data were processed using SPSS.v.20 software and were presented in percentage, average value, and range. All data obtained in this study are kept confidential and obtained with the approval of the patients.

\section{RESULTS}

A total of 51 patients were included. Most of patients were female $(64.7 \%)$, age more than 60 years (41.2\%), BMI $18.5-23.5 \mathrm{~kg} / \mathrm{m} 2(62.7 \%)$, no history of knee trauma (92.2\%), and stage 2 of OA KL (54.9\%). Complete clinical profile data can be seen in table 1 . Table 2 describes the profile of Quality of life among knee OA patients. We found the most proportion of patients reporting 'no problem' on the 'anxiety/depression' dimension and the lowest on the 'pain/discomfort' dimension. Only a few patients had 'very poor' status, which was highest in the 'usualactivity' dimension and lowest in the 'anxiety/depression' and 'mobility' dimensions. Among all dimensions, most patients had some problems in 'pain/discomfort' and 'mobility'

Table-1: The Clinical Profile of Knee OA Patients
\begin{tabular}{|l|l|}
\hline Variable & Frequency n $(\%)$ \\
\hline Sex & $33(64.7)$ \\
\hline Female & $18(35.3)$ \\
\hline Male & $3(5.9)$ \\
\hline Age (years) & $9(17.6)$ \\
\hline $31-40$ & $18(35.3)$ \\
\hline $41-50$ & $21(41.2)$ \\
\hline $51-60$ & $5(9.8)$ \\
\hline$>60$ & $32(62.7)$ \\
\hline Body mass index (kg/m2) \\
\hline$<18.5$ & $14(27.5)$ \\
\hline IMT 18.5-23.5 & $4(7.8)$ \\
\hline IMT >23.5 & $47(92.2)$ \\
\hline History of knee trauma \\
\hline Yes & 4 Kellgren- Lawrence \\
\hline No & $5(9.8)$ \\
\hline Degree of OA Ke & $28(54.9)$ \\
\hline Grade 1 & $14(27.5)$ \\
\hline Grade 2 & $4(7.8)$ \\
\hline Grade 3 & \\
\hline Grade 4 & \\
\hline
\end{tabular}

Table-2: Distribution of Quality of life among Knee OA Patients Using EQ-5D-3L Instrument

\begin{tabular}{|l|l|l|l|l|l|}
\hline $\begin{array}{l}\text { Descriptive Variables } \\
\mathbf{N = 5 1}\end{array}$ & $\begin{array}{l}\text { Mobility n } \\
(\boldsymbol{\%})\end{array}$ & $\begin{array}{l}\text { Self-care n } \\
(\boldsymbol{\%})\end{array}$ & $\begin{array}{l}\text { Usual activity } \\
\mathbf{n}(\boldsymbol{\%})\end{array}$ & $\begin{array}{l}\text { Pain/ Discomfort } \\
\mathbf{n}(\boldsymbol{\%})\end{array}$ & $\begin{array}{l}\text { Anxiety/ } \\
\text { Depression n }(\boldsymbol{\%})\end{array}$ \\
\hline No problems & $35(68.6)$ & $41(80.4)$ & $36(70.6)$ & $10(19.6)$ & $45(88.2)$ \\
\hline Some problems & $16(31.4)$ & $6(11.8)$ & $9(17.6)$ & $39(76.5)$ & $6(11.8)$ \\
\hline $\begin{array}{l}\text { Extreme problems/ not } \\
\text { be able to }\end{array}$ & $0(0.0)$ & $4(7.8)$ & $6(11.6)$ & $2(3.9)$ & $0(0.0)$ \\
\hline
\end{tabular}

\section{DISCUSSION}

The prevalence of OA is quite high among the elderly as stated from the American College of Rheumatology (ACR) 1986 clinical diagnosis criteria which is age over 50 years. Knee OA has negative impact on Quality of life [5, 6]. The EQ-5D instruments have been shown to be valid and reliable instruments for evaluating Quality of life in patients with knee OA [7]. In this study, we found the age group $>60$ years old had the highest prevalence of knee OA (41.2\%) with male to female ratio $1: 1.8$. Similar studies reported most knee OA patients were female $[5,6,8,10]$ with the age more than 60 years $[5,9,10]$. Maharani EP et al. reported female gender was one of the risk factors for OA (OR 2.14, $\mathrm{p}=0.043$ ) [11]. This is in line with the concept of theory which states that the frequency of OA is more common in women after menopause in the age of 50 years or more. Majority of knee OA patients in this study were in grade 2-3 KL (82.4\%) with BMI $18.5-23.5 \mathrm{~kg} / \mathrm{m} 2(62.7 \%)$, followed by BMI $>23.5$ $\mathrm{kg} / \mathrm{m} 2(27.5 \%)$. Despite higher BMI is known as risk factor for knee OA, the results of this study seem a little different. Most of patients in this study had normal BMI. Some studies in Indonesia also reported normal BMI among knee OA patients $[11,12]$. Previous study revealed higher grade of KL among knee OA patients [8]. Most of patients were grade 3-4 KL in knee OA patients [8]. BMI was associated with severity of OA. In our study, most patients were in BMI 18.5-23.5 $\mathrm{kg} / \mathrm{m} 2$ or normal BMI $(62.7 \%)$, but in Nikolic et al. most patients had mean of BMI $30.0 \pm 3.0$ (obese) [8]. This might explain why most of the patients in this study had lower grade of KL than previous study. Based the EQ-5D-3L instrument, Quality of life was divided into five dimensions including mobility, self-care, usual activity, pain/discomfort, and anxiety / depression. Every dimension has three levels of problems including no problems, some problems, and extreme problem/not able to [4]. Usual activity means the ability of patients in doing housework, family or leisure activities, and work [4]. We found the highest proportion of patients reporting 'no problem' was on the 'anxiety/depression' dimension $(88.2 \%)$ and the lowest on the 
'pain/discomfort' dimension (19.6\%). Only a few patients had 'very poor' status, which was highest in the 'usual-activity' dimension $(11.6 \%)$ and lowest in the 'anxiety/depression' ( $0 \%)$ and 'mobility' dimensions $(0 \%)$. Nikolic et al. reported that age was associated with usual activity [8]. Some patients experienced very poor status in 'usual activity' domain might be caused by majority of patients in this study is in elder age ( $>60$ years). Shrestha et al. reported OA patients had more significant proportion of physical health problems than mental health problems [13]. It might be explained the cause of low problems in 'anxiety/depression' domain in this study. However, other study showed the opposite [5]. Therefore, attention should not only focus on physical aspects, but also on mental health aspects. Among all dimensions, most patients had some problems in 'pain/discomfort' $(76.5 \%)$ dimension and 'mobility' dimension (31.4\%). Nikolic et al. reported age and degree of KL were associated with 'pain/discomfort' in knee OA patients [8]. This study also reported that severity of clinical manifestation and radiological findings affected the functional ability and Quality of life of knee OA patients [8]. Approximately $70 \%$ of patients in our study experienced some problems with 'pain/discomfort', this is probably caused by $70 \%$ of patients had severity degree of knee OA grade 2-3 KL, thus affecting the mobility. The patients in this study overall had good Quality of life because most of them did not have problems in functional abilities and mental health.

\section{Limitations of the study}

This is a single center study with small sample size. So, the study results may not be representative for actual generalization.

\section{Conclusion}

Majority of patients in this study had good Quality of life. This needs to be maintained and improved so that knee OA patients do not fall into poor Quality of life. More attention, proper management, and modification of modifiable risk factors can give positive impact on knee OA patients.

\section{REFERENCES}

1. Wood AM, Brock TM, Heil K, Holmes R, Weusten A. A review on the management of hip and knee osteoarthritis. International journal of chronic diseases. 2013, 2013.
2. Litwic A, Edwards MH, Dennison EM, Cooper C. Epidemiology and burden of osteoarthritis. British medical bulletin. 2013; 105(1):185-99.

3. Kohn MD, Sassoon AA, Fernando ND. Classifications in brief: Kellgren-Lawrence classification of osteoarthritis; 2016.

4. Reenen MV, Oppe M. EQ-5D-3L user guides. EuroQuality of life Research Foundation: Netherland; 2015.

5. Alrushud AS, El-Sobkey SB, Hafez AR, AlAhaideb A. Impact of knee osteoarthritis on the quality of life among Saudi elders: A comparative study. Saudi Journal of Sports Medicine. 2013; 13(1):10.

6. Verges J, Vitaloni M, Bibas M, Sciortino R, Quintero M, Monfort J, Carné X, de Abajo F, Oswald E, Matucci M, du Souich P. Global OA management begins with quality of life assessment in knee OA patients: a systematic review. Osteoarthritis and Cartilage. 2019 Apr 1;27:S22930.

7. Wailoo A, Alava MH, Martinez AE. Modelling the relationship between the WOMAC osteoarthritis index and EQ-5D. Health and quality of life outcomes. 2014; 12(1):37.

8. Nikolic G, Nedeljkovic B, Trajkovic G, Rasic D, Mirkovic Z, Pajovic S, Grbic R, Sipetic S, Vujcic I. Pain, Physical Function, Radiographic Features, and Quality of Life in Knee Osteoarthritis Agricultural Workers Living in Rural Population. Pain Research and Management. 2019 Sep 29;2019.

9. Fernandez-Cuadros ME, Pérez-Moro OS, MironCanelo JA. Knee osteoarthritis: Impact on quality of life and effectiveness of total knee arthroplasty. Divers Equal Health Care. 2016; 13(4):278-83.

10. Abbott JH, Usiskin IM, Wilson R, Hansen P, Losina E. The quality-of-life burden of knee osteoarthritis in New Zealand adults: A modelbased evaluation. PloS one, 2017; 12(10).

11. Maharani EP. Faktor-faktor risiko osteoartritis lutut. Semarang: Universitas Diponegoro Semarang. 2007; (14).

12. Hasiibi W. Prevalensi Dan Distribusi Osteoartritis Lutut Berdasarkan Karakteristik Sosio-Demografi Dan Faktor Risiko Di Wilayah Kerja Puskesmas Susut I, Kecamatan Susut, Kabupaten Bangli Pada Tahun 2014. Intisari Sains Medis. 2015; 4(1):3241. 